\title{
Transparansi Pelayanan Izin Mendirikan Bangunan (IMB) di Kantor Badan Pelayanan Perizinan Terpadu Kabupaten Mamuju
}

\author{
${ }^{1}$ Rudi, ${ }^{2}$ Muhammad Yunus, ${ }^{3}$ Hasrat Arief Saleh \\ ${ }^{1}$ Universitas Tomakaka,Mamuju \\ ${ }^{2}$ Fakultas Ilmu Sosial dan Politik,Universitas Hasanuddin,Makassar \\ ${ }^{3}$ Fakultas Ilmu Sosial dan Ilmu Politik,Universitas Hasanuddin,Makassar \\ Mamuju,Indonesia \\ Email: rudiamru@gmail.com
}

\begin{abstract}
Transparency of the services provided by government agencies in administering public services is very important so customer can easily find out information or access about the procedure / stages in the services provided by her government agencies. The aim of the research is to describe, measure and analyse the transparency of building construction permit in Mamuju Regency. The research was a descriptive qualitative and quantitative (mix method) study. The methods of obtaining the data were questionnaire, interview and observation to informants who are directly involved in building construction permit. The results of the research indicate that the implementation process of service transparency of building construction permit in Mamuju Regency has not been fully implemented based on transparency dimensions expected by the customers/community. There are still some points that should be informed clearly and precisely to the costomers/community especially in terms of service implementation management, technical and administrative requirements, service completion time, authorized and responsible officials, service appointments, service location, and service standard. Meanwhile, the points that can meet the transparency dimensions are service procedure, service cost, and information of service consultation/complaint process that are sufficient to provide information that is clear, precise, and easy to understand. The lack of transparency of the points mentioned above is because the authorized and responsible officials do not have commitment in providing clear and precise information for the costomers/community, so a certainty in service is not created.
\end{abstract}

Keywords: Transparency; Service; IMB

\section{Abstrak}

Transparansi pelayanan sangat penting bagi instansi pemerintah dalam penyelenggaraan pelayanan publik, karena dengan adanya transparansi pelayanan terhadap masyarakat/pelanggan dapat dengan mudah mengetahui informasi atau akses tentang prosedur-prosedur dalam pelayanan yang diberikan olen instansi pemerintah. Penelitian ini bertujuan menggambarkan, mengukur, dan menganalisa transparansi pelayanan izin mendirikan bangunan (IMB) di Kabupaten Mamuju. Penelitian ini merupakan penelitian deskriptif kualitatif dan kuantitatif (mix method). Data dikumpulkan melalui kuesioner, wawancara, dan observasi terhadap informan yang terlibat langsung dalam pelayanan IMB. Hasil penelitian menunjukkan bahwa proses penerapan transparansi pelayanan IMB Kabupaten Mamuju belum sepenuhnya diterapkan dalam dimensi-dimensi transparansi yang diharapkan oleh masyarakat. Masih terdapat beberapa aspek yang harus diinformasikan secara jelas dan tepat kepada masyarakat terutama dari segi manajemen penyelenggaraan pelayanan, persyaratan teknis dan administrasi, waktu penyelesaian pelayanan, pejabat yang berwenang dan bertanggung jawab, janji pelayanan, lokasi pelayanan, dan standar pelayanan. Adapun aspek yang telah memenuhi dimensidimensi transparansi, yaitu prosedur pelayanan, biaya pelayanan dan informasi proses konsultasi/pengaduan pelayanan sudah memberikan informasi yang jelas, tepat, dan mudah dipahami.

Kata kunci : Transparansi; Pelayanan; IMB

Link DOI : $\underline{\text { http://dx.doi.org/10.31314/pjia.7.1.53-62.2018 }}$

Copyright @ 2018, Publik : (Jurnal Ilmu Administrasi), ISSN: 2301-573X (Print), ISSN: 2581-2084 (Online) 


\section{PENDAHULUAN}

Berdasarkan Keputusan Menteri Pendayagunaan Aparatur Negara Nomor 26 tahun 2004 tentang Petunjuk Teknis Transparansi dan Akuntabilitas dalam penyelenggaraan pelayanan publik meliputi: (1) manajemen dan penyelenggaraan pelayanan publik; (2) prosedur pelayanan; (3) persyaratan teknis dan administrasi pelayanan; (4) rincian biaya pelayanan; (5) waktu penyelesaian pelayanan; (6) pejabat yang berwenang dan bertanggung jawab; (7) lokasi pelayanan; (8) janji pelayanan; (9) standar pelayanan dan, (10) informasi pelayanan. Hal ini menunjukkan bahwa didalam pelayanan publik, prinsip transparansi merupakan suatu prinsip pokok disamping prinsipprinsip pokok lain harus diterapkan dalam pelayanan publik untuk mewujudkan pelayanan publik yang berkualitas. Menurut Ratminto \& Winarsih (2005), buruknya kinerja pelayanan publik, antara lain dikarenakan belum dilaksanakannya transparansi dalam penyelenggaraan pelayanan publik. Oleh karena itu, pelayanan publik harus dilaksanakan secara transparan oleh setiap unit pelayanan instansi pemerintah, karena kualitas kinerja birokrasi pelayanan publik memiliki implikasi yang luas dalam mencapai kesejahteraan masyarakat

Sesuai dengan Peraturan Daerah Nomor 9 Tahun 2011, Tentang Perubahan Perda No.12 Tahun 2007 Tentang Pembentukan Organisasi Lembaga Teknis Daerah Kabupaten Mamuju, Badan Pelayanan Perizinan Terpadu (BPPT) Kabupaten Mamuju mempunyai tugas melaksanakan koordinasi dan penyelenggaraan serta pelayanan administrasi di bidang perizinan secara terpadu dengan prinsip koordinasi, integrasi, sinkronisasi, simplifikasi dan keamanan. Hal ini menunjukkan konsistensi dan komitmen Pemerintah Kabupaten Mamuju dalam rangka meningkatkan pelayanan kepada masyarakat di bidang perizinan, namun dalam pelaksanaannya masih terdapat beberapa permasalahan yang terjadi dalam penyelenggaraan pelayanan IMB di kantor BPPT yaitu kurang transparansinya dalam pelayanan teknis dan administrasi pelayanan, waktu penyelesaian pelayanan, pejabat yang berwenang dan bertanggung jawab dalam pelayanan, dan kurangnya akses informasi dan pengaduan pelayanan perizinan dengan tidak adanya website dan media pengaduan dalam pelayanan izin mendirikan bangunan (IMB) di Kantor Badan Pelayanan Perizinan Terpadu (BPPT) Kabupaten Mamuju.

Dalam paradigma baru pelayanan publik saat ini memperkenalkan sebuah konsep atau model yang dikenal dengan New Public Service. Menurut Keban (2008), paradigma pelayanan publik baru ini adalah bahwa birokrasi harus dibangun agar dapat memberikan perhatian pada pelayanan masyarakat sebagai warga negara, mengutamakan kepentingan publik, mengikutsertakan warga masyarakat, bertindak demokratis, memperhatikan norma, nilai dan standar yang ada dan menghargai masyarakat. Jelas bahwa dalam memberikan pelayanan pemerintah harus bersifat terbuka terhadap masyarakat dengan memperhatikan aspek transparansinya.

Menurut Dwiyanto (2008), setidaknya ada 3 indikator yang dapat digunakan untuk mengukur transparansi pelayanan publik, pertama penilaian terhadap tingkat keterbukaan meliputi seluruh proses pelayanan publik, termasuk didalamnya adalah persayaratan, biaya dan waktu yang dibutuhkan serta meknisme/prosedur pelayanan yang harus dipenuhi. Persyaratan pelayanan harus 
dipublikasikan secara terbuka dan mudah diketahui oleh para pengguna. Kedua kemudahan dalam memahami peraturan dan prosedur pelayanan. Penjelasan mengenai persyaratan, prosedur, biaya dan waktu yang diperlukan sebagaimana adanya merupakan hal yang sangat penting bagi para pengguna. Ketiga kemudahan untuk memperoleh informasi mengenai berbagai aspek penyelenggaraan pelayanan publik. Semakin mudah pengguna memperoleh informasi mengenai berbagai aspek penyelenggaraan pelayanan publik semakin tinggi transparansi.

Indikator yang digunakan dalam melihat transparansi pelayanan menurut Ratminto \& Winarsih (2014), terdapat sepuluh dimensi transparansi pelayanan, yaitu: manajemen dan penyelenggaraan pelayanan, prosedur pelayanan, persyaratan Teknis dan administrasi pelayanan, perincian biaya pelayanan, waktu penyelesaian pelayanan, pejabat yang berwenang dan bertanggung jawab, janji pelayanan, standar pelayanan, lokasi pelayanan, Informasi dan konsultasi/pengaduan pelayanan.

Penelitian terdahulu mengenai transparansi pelayanan dilakukan oleh Dunan (2011), "Transparansi Pelayanan Pada Perusahaan Daerah Air Minum (PDAM) Kota Ambon'. Penelitian ini bertujuan untuk menjelaskan penerapan transpatansi pelayanan Perusahaan Daerah Air Minum (PDAM) Kota Ambon. Kesimpulan dalam penelitiannya adalah dalam penyelenggaraan pelayanan belum sesuai apa yang diharapkan dalam penerapan dimensi transparansi pelayanan terutama dalam prosedur pelayanan, persyaratan teknis dan administrasi pelayanan, waktu penyelesaian pelayanan, pejabat yang berwenang dan bertanggung jawab, janji pelayanan, lokasi pelayanan, dari beberapa indikatot tersebut belum memberikan informasi yang jelas kepada Copyright @ 2018, Publik : (Jurnal Ilmu Administrasi), ISSN: 2301-573X (Print), ISSN: 2581-2084 (Online) masyarakat/pelanggan, sedangkan yang dapat memenuhi dimensi transparansi pelayanan adalah dari segi perincian biaya yang terperinci dengan jelas dan standar pelayanan jelas dan tepat.

Dalam penelitian ini dilakukan dengan tujuan untuk menggambarkan, mengukur dan menganalisa transparansi pelayanan IMB yang dilakukan oleh Badan Pelayanan PerizinanTerpadu Kabupaten Mamuju.

\section{METODE PENELITIAN}

Penelitian ini menggunakan pendekatan yang menggabungkan antara pendekatan kualitatif dengan pendekatan kuantitatif, dalam era kontemporer lebih dikenal dengan mixed-methods approach (Brannen, 2005). Dengan demikian berdasarkan hal itu, maka dalam penelitian ini digunakan pendekatan kualitatif sebagai pendekatan sekunder (utama/pengarah) dan pendekatan kuantitatif sebagai pendekatan (penunjang) atau lebih tepatnya paradigma penelitian ini adalah Kualititif+Kuantitatif.

Lokasi penelitian tentang transparansi pelayanan dilakukan di Kantor Badan Pelayanan Perizinan Terpadu Kabupaten Mamuju. Berdasarkan mixed methods research adalah mengkombinasikan teknik pengumpulan data antara kualitatif dengan kuantitatif (Sugiono, 2011). Data yang diperoleh yakni dengan cara mengedarkan kuesioner/daftar pertanyaan tertulis kepada responden dengan jumlah sampel sebanyak 30 orang yang terlibat langsung dalam pelayanan IMB pada BPPT Kabupeten Mamuju. Wawancara dan observasi yang berhubungan dengan fokus penelitian. Adapun informan dari unsur pemerintah yang terkait fokus penelitian tentang transparansi pelayanan, diantaranya : Kepala BPPT, Kepala Dinas Tata Ruang dan Kebersihan, Kepala Bidang Pelayanan BPPT, Kepala Seksi Pelayanan BPPT, 
Pegawai Unit Pelayanan BPPT Kabupaten Mamuju.

Data yang telah terkumpul akan diolah melalui teknik dianalisa secara kualitatif dan kuantitatif sesuai tahap-tahap yaitu : Editing, Coding, Tabulasi Data, yaitu mencatat semua jawaban responden mulai dari responden pertama sampai terakhir. Skala pengukuran yang digunakan adalah skala likert yang ditentukan bagi setiap pilihan jawaban, dengan skala 1-5 yang ditabulasi. Dari hasil tabulasi akan diperoleh variasi jawaban responden berdasarkan pembobotan (skor) dari masing-masing pilihan jawaban. Data yang di kumpulkan di analisis dengan menggunakan teknik analisis deskriptif kualitatif dengan mengunakan bantuan tabel frekuensi.

\section{HASIL DAN PEMBAHASAN}

Gambaran

Transparansi penyelenggaraan pelayanan publik adalah pelayanan secara terbuka, mudah dan dapat diakses oleh semua pihak yang membutuhkan serta tersedianya sarana prasarana yang memadai dan mudah dimengerti. Penerapan transparansi pelayanan izin mendirikan bangunan (IMB) di Kantor BPPT Kabupaten Mamuju, indikator yang digunakan untuk mengukur transparansi pelayanan yaitu: manajemen penyelenggaraan pelayanan, prosedur pelayanan, persyaratan teknis dan administrasi pelayanan, perincian biaya pelayanan, pejabat yang berwenang dan bertanggung jawab, janji pelayanan, standar pelayanan, lokasi pelayanan, informasi dan proses pengaduan pelayanan

\section{Pertama,} manajemen penyelenggaraan pelayanan yang meliputi transparansi dalam perencanaan, pelaksanaan dan pengawasan penyelenggaraan pelayanan publik yang merupakan pelaksanaan tugas dan kegiatan yang bersifat terbuka bagi masyarakat dari proses kebijakan yang mudah diakses oleh semua pihak yang membutuhkan informasi. Berdasarkan jawaban responden pada hasil penelitian bahwa indikator manejemen penyelenggaraan pelayanan publik pada BPPT Kabupaten Mamuju, menunjukkan bahwa kurang jelas dalam memberikan informasi dalam penyelenggaraan pelayanan, dengan tidak kejelasnya kebijakan pada BPPT mengakibatkan tidak optimalnya penyelenggaraan pelayanan perizinan Kabupaten Mamuju.

Kedua, prosedur pelayanan adalah merupakan tahapan-tahapan yang harus dipenuhi oleh masyarakat dalam mengurus perizinan, prosedur pelayanan seharusnya mudah dipahami dan tidak berbelit-belit dan dapat diakses oleh masyarakat. Berdasarkan pada hasil penelitian bahwa indikator transparansi dilihat dari segi prosedur pelayanan pada Kantor BPPT Kabupaten Mamuju, menunjukkan bahwa adanya kejelas dalam memberikan informasi dalam prosedur pelayanan IMB pada Kantor BPPT Kabupaten Mamuju. Dengan adanya kejelasan informasi yang didapatkan oleh masyarakat akan memberikan pedoman untuk syarat-syarat yang harus dipenuhi dalam pelayanan IMB

Ketiga, persyaratan teknis dan administrasi pelayanan adalah merupakan prasyarat pelayanan yang harus dipenuhi terlebih dahulu untuk mendapatkan pelayanan sesuai dengan jenis pelayanan yang dibutuhkan. Berdasarkan pernyataan responden pada hasil penelitian mengenai indikator transparasi dilihat dari persyaratan teknis dan administrasi pelayanan IMB pada Kantor BPPT Kabupaten Mamuju, menunjukkan bahwa kurang jelas dalam persyaratan teknis dan administrasi pelayanan IMB pada Kantor 
Publik : (Jurnal Ilmu Administrasi) Vol 7 (1), Juni 2018

Badan Pelayanan Terpadu Kabupaten Mamuju. Dengan demikian bahwa masyarakat sebagai pengguna layanan kurang mendapatkan informasi yang jelas tentang syarat-syarat yang harus dipenuhi oleh masyarakat dalam mengurus IMB, sehingga dapat menghambat proses penyelesaian pelayanannya.

Keempat, perincian biaya pelayanan adalah keseluruhan biaya yang harus dibayarakan sesuai yang telah ditetapakan bagi penyelenggara pelayanan, dalam perincian biaya pelayanan harus diinformasikan secara jelas kepada masyarakat agar memudahkan untuk merincikan biaya dalam pelayanan. Berdasarkan pernyataan responden pada hasil penelitian dalam rincian biaya pelayanan izin mendirikan bangunan (IMB), menyatakan bahwa adanya kejelasan yang ditampilakan oleh BPPT Kabupaten Mamuju, sehingga masyarakat dapat mengerti dan mengetahui banyaknya yang harus disiapkan dalam pelayanan IMB.

Kelima, jangka waktu penyelesaian pelayanan adalah jangka waktu yang diberikan kepada masyarakat sebagai pengguna layanan dalam penyelesaian pelayanan IMB. Kejelasan waktu pelayanan merupakan wujud dari kualitas pelayanan serta menjadi tolak ukur dalam memberikan pelayanan kepada masyarakat. Berdasarkan pernyataan responden pada hasil penelitian menunjukkan bahwa kurang jelasnya dalam menginformasikan waktu penyelesaian pelayanan IMB kepada masyarakat/pelanggan. Sehingga masyarakat kurang mendapatkan kepastian batas waktu pelayanan yang diberikan oleh pihak BPPT Kabupaten Mamuju.

Keenam, pelayanan publik diselenggarakan oleh pejabat publik dalam suatu organisasi pemerintahan, setiap pejabat publik memiliki kewenangan dan Copyright () 2018, Publik : (Jurnal Ilmu Administrasi), ISSN: 2301-573X (Print), ISSN: 2581-2084 (Online) tanggung jawab tertentu untuk memberikan pelayanan dalam jenis pelayanan tertentu. Kejelasan tentang pejabat yang berwenang dan bertanggung jawab dalam pelayanan sangat dibutuhkan untuk dapat memperlancar proses pemberian pelayanan dan memberikan kepastian kepada masyarakat pengguna layanan kepada siapa mereka untuk mendapatkan pelayanan. Berdasarkan jawaban responden pada hasil penelitian menggambarkan bahwa pejabat BPPT Kabupaten Mamuju kurang menampilkan kejelasan dan kepedulian terhadap proses pelayanan, Pejabat yang berwenang dan bertanggung jawab dalam penyelenggaraan pelayanan harus mampu menyelesaikan keluhan, persoalan dan sengketa, maka harus ada jelas yang bertanggung jawab dalam pelayanan perizinan.

Ketujuh, janji pelayanan adalah merupakan suatu komitmen pejabat yang berwenang dalam pelayanan bentuk slogan secara tertulis yang berisi motivasi untuk membangun kepastian dan kepercayaan atas jasa pelayanan yang diberikan dan diwujudkan secara tertulis dan dinformasikan kepada masyarakat sebagai pengguna jasa pelayanan. Berdasarkan jawaban responden pada hasil penelitian terhadap janji pelayanan IMB pada Kantor BPPT Kabupaten Mamuju, menunjukkan bahwa kurang menberikan kejelasan dalam janji pelayanan. Masyarakat/pelanggan kurang mendapatkan informasi secara tertulis dari pejabat yang berwenang dalam pelayanan IMB yang berbentuk slogan atau motto yang ditampilkan guna untuk mengetahui esensi dari pelayanan BPPT kabupaten Mamuju.

Kedelapan, standar pelayanan publik adalah suatu tolok ukur yang dipergunakan sebagai pedoman penyelenggaraan pelayanan dan acuan penilaian kualitas pelayanan sebagai komitmen atau janji dari penyelenggara , ISSN: 2301-573X (Print), ISSN: 2581-2084 
pelayanan kepada masyarakat untuk memberikan pelayanan yang berkualitas. Standar pelayanan merupakan suatu kewajiban pejabat untuk merumuskan dan menyediakan untuk kepentingan pelanggan/masyarakat agar kenyamanan dalam pelayanan dapat tercapai. Berdasarkan jawaban responden pada hasil penelitian terhadap standar pelayanan menunjukkan bahwa kurang memberikan kejelasan terhadap standar pelayanan, yakni pelayanan yang dijalankan kurang memenuhi standar pelayanan yang jelas sebagai ukuran bagi pelayanan yang berkualitas dalam melayani masyarakat sebagai pengguna layanan.

Kesembilan, lokasi pelayanan adalah tempat yang telah ditentukan dalam memberikan pelayanan. Adapun lokasi pelayanan yang disediakan harus memenuhi standar pelayanan yang mudah dan cepat serta mudah dijangkau dalam pelayanan. Lokasi pelayanan harus dilengkapi dengan fasilitas pelayanan yang dapat menunjang proses pelayanan bagi masyarakat. Berdasarakan pernyataan responden pada hasil penelitian terhadap lokasi pelayanan IMB menunjukkan bahwa yang menyatakan kurang jelas terhadap transparansi lokasi pelayanan pada BPPT Kabuapaten Mamuju, masyarakat dalam mengurus IMB masih sering diarahkan ke Dinas Tata Ruang yang semstinya pelayanan IMB sudah sepenuhnya ditangani oleh BPPT Kabupaten Mamuju, kurangnya koordinasi Pejabat yang berwenang dalam memberikan kepastian yang jelas terhadap lokasi pelayanan IMB sehingga masyarakat tidak mengetahu secara pasti tempat yang sesunguhnya dalam pelayanan IMB.

Kesepuluh, Informasi dan pengaduan pelayanan adalah masukan dari masyarakat baik berupa informasi, saran, pendapat, tanggapan dan atau pengaduan, hendaklah ditindak lanjuti dengan langkah upaya perbaikan pelayanan oleh unit pelayanan. Jika dalam pengaduan terdapat masyarakat yang dirugikan dalam pelayanan. Pengaduan baik berupa tertulis atau media elektronik, harus disampaikan secara jelas dan bertanggung jawab serta memberikan penjelasan yang mudah dimegerti oleh masyarakat yang membutuhkan informasi dalam pelayanan. Berdasarkan pernyataan responden pada hasil penelitian terhadap informasi konsultasi/pengaduan pelayanan menunjukkan bahwa adanya kejelasan dalam memberikan informasi kosultasi/pengaduan pelayanan. Masyarakat/pelanggan sudah mendapatakan sarana informasi pengaduan yang berupa kotak saran dan call center yang dapat dihubungi untuk keluhan pelayanan.

\section{Pembahasan}

Penelitian ini memperlihatkan bahwa transparansi pelayanan izin mendirikan bangunan (IMB) dikantor BPPT Kabupaten Mamuju belum menunjukkan hasil yang optimal dalam penerapan transparansi pelayanan IMB, masih ada beberapa dimensi transparansi pelayanan yang harus diinformasikan secara jelas, mudah diakses oleh masyarakat. Keterbukaan informasi pelayanan yang belum jelas, akhirnya menimbulkan ketidaklancarannya dalam pelayanan IMB. Dalam mewujudkan transparansi pelayanan IMB setidaknya harus memperhatikan dimensi-dimensi transparansi pelayanan.

Analisis kejelasan manajemen penyelenggaraan pelayanan yaitu kejelasan dalam kebijakan mulai dari perencanaan sampai pada pelaksanaan pelayanan yang dilakukan oleh penyelenggara pelayanan, dimaksud dengan tujuan agar pelayanan 
Publik : (Jurnal Ilmu Administrasi) Vol 7 (1), Juni 2018

yang dilakukan oleh BPPT Kabupaten Mamuju dapat berjalan sesuai dengan standar pelayanan yang telah ditentukan. Sehubungan dengan kurang jelasnya terhadap manajemen penyelenggaraan pelayanan pada BPPT Kabupaten Mamuju sebagai wujud kurangnya komitmen dari pejabat yang berwenang dalam merencanakan, melaksanakan serta melakukan pengawasan secara baik dan konsisten serta kegiatan yang bersifat terbuka dalam pelayanan IMB. Ketidakjelasan kebijakan dalam pelayanan akan memberikan dampak terhadap pelaksanaan pelayanan sehingga kualitas dari pelayanan yang kurang maksimal.

Analisis kejelasan prosedur pelayanan yaitu Pejabat yang berwenang dan bertanggung jawab telah memberikan informasi yang jelas kepada masyarakat dalam prosedur pelayanan IMB. Namun masih perlu pembenahan terutama pada Bagan Alir (Flow Chart) yang lebih simpel dan lebih praktis sebagai bentuk kemudahan tahapan-tahapan yang diberikan kepada masyarakat pengguna layanan. Dengan adanya prosedur pelayanan yang lebih praktis dan kesederhanaan alur pelayanan, maka akan memudahkan masyarakat dalam pengurusan IMB. Prosedur pelayanan harus sederhana tidak berbeli-belit mudah dipahami, dilaksanakan diwujudkan dalam bentuk Bagan Alir (Flow Chart) yang dipampang dalam ruangan pelayanan (Ratminto \& Winarsih, 2014).

Analisis kejelasan persyaratan teknis dan administrasi pelayanan yaitu Persyaratan yang harus dipenuhi oleh masyarakat dalam pelayanan, persyaratan tersebut harus di tampilkan secara jelas dan lengkap sesuai dengan ketentuan yang telah ditetapkan serta mudah dipenuhi oleh masyarakat. Dari hasil penelitian menunjukkan bahwa persyaratan teknis dan administrasi pelayanan IMB pada
BPPT Kabupaten Mamuju kurang menampilkan dengan jelas kepada masyarakat. Dalam menentukan persyaratan teknis maupun administrasi harus seminimal mungkin dikaji terlebih dahulu agar benar-benar sesuai/relevan dengan jenis pelayanan yang diberikan. Harus dihilangkan persyaratan yang bersifat duplikasi dari instansi terkait dengan proses pelayanan.persyaratan tersebut harus dinformasikan secara jelas dan diletakkan di dekat loket pelayanan, ditulis dengan hurup cetak dan dapat dibaca dalam jarak pandang minimum (3) meter atau disesuaikan dengan kondisi ruangan (Ratminto \& Winarsih, 2014).

Analisis kejelasan perincian biaya pelayanan yaitu kejelasan rincian biaya yang dikeluarkan dalam pengurusan, artinya bahwa masyarakat dapat mengkalkulasi besaran biaya yang akan dikeluarkan sesuai dengan telah ditetapkan oleh BPPT Kabupeten Mamuju. Dari hasil penelitian menunjukkan bahwa perincian biaya pelayanan sudah ditampilkan dengan jelas kepada masyarakat, namun masih perlu adanya pembenahan sistem pelayanan pembayaran IMB, yang seminimal mungkin menghindari pertemuan personal antara pemohon dengan pemberi pelayanan secara langsung, hendaknya pembayaran yang dilakukan melalui bank pemerintah yang ditunjuk yang sesuai dengan rekomendasi tarif yang ditetapkan BPPT Kabupaten Mamuju.

Analisis kejelasan pejabat berwenang dan bertanggung jawab yaitu pejabat dalam penyelenggaraan pelayanan dituntut untuk harus mampu menyelesaikan keluhan, persoalan dan sengketa serta memberikan kepedulian, kepastian pelayanan sehingga akan membangun citra positif terhadap masyarakat. Keberadaan dan kejelasan pejabat yang berwenang dan bertanggung jawab harus mampu memberikan solusi Copyright (C) 2018, Publik : (Jurnal Ilmu Administrasi), ISSN: 2301-573X (Print), ISSN: 2581-2084 (Online) 
dalam pelayanan IMB pada BPPT Kabupaten Mamuju, dengan cara-cara yang santun terhadap masyarakat dan ditandai dengan identitas yang jelas sesuai dengan surat penugasan atau surat keputusan yang bersifat formal. Dalam penerapan prinsip New Publik Management, pemerintah yang harus berorientasi pada pelayanan publik, sehingga pemerintah memandang masyarakat sebagai faktor dominan dalam menentukan apa yang dibutuhkan, kemudian pemerintah memenuhi kebutuhan tersebut demi mewujudkan kepuasan dan kesejahteraan masyarakat (Frederickson \& Smith, 2002).

Analisis kejelasan janji pelayanan yaitu penerapan janji pelayanan merupakan komitmen pejabat yang berwenang dan bertanggung jawab dalam pelayanan untuk memberikan informasi secara tertulis dan jelas yang menyangkut tentang esensial yang didalamnya mengenai standar kualitas pelayanan (Ratminto \& Winarsih, 2014). Berdasarkan dengan itu, janji pelayanan yang ada di Kantor BPPT Kabupaten Mamuju harus diwujudkan dalam bentuk memberikan komitmen yang jelas secara tertulis dalam melayani masyarakat. Dimaksudkan untuk memberikan keabsahan identitas dan kepastian dalam pelayanan serta memberikan perlindungan status hak pelayanan kepada masyarakat. Dengan adanya janji yang dapat ditampilkan jelas dalam pelayanan publik akan memberikan semangat, baik kepada pemberi maupun penerima layanan.

Analisis kejelasan standar pelayanan publik adalah suatu tolok ukur dari penyelenggara pelayanan kepada masyarakat untuk memberikan pelayanan yang berkualitas. Standar pelayanan minimal merupakan suatu kewajiban pejabat/pegawai untuk merumuskan dan menyediakan bagi kepentingan masyarakat agar kenyamanan dalam pelayanan dapat tercapai. Berdasarkan hasil temuan dalam memberikan penjelasan dan informasi tentang standar pelayanan IMB pada BPPT Kabupaten Mamuju tidak menampilkan dan mempublikasikan secara jelas, serta tidak ada bentuk kepedulian dan komitman pejabat yang berwenang dalam menyusun suatu standar yang dapat dijadikan panduan dalam melayani masyarakat.

Analisis kejelasan lokasi pelayanan adalah tempat yang ditentukan dalam memberikan pelayanan, lokasi pelayanan harus jelas sehingga mereka tidak lagi bertanya-tanya kemana dan dimana mereka akan mendapatkan pelayanan. Lokasi pelayanan diusahkan harus tetap dan tidak berpindah-pindah, mudah dijangkau oleh pemohon pelayanan, dilengkapi sarana dan prasarana yang memadai termasuk sarana telekomunikasi dan informatika (telematika). Hasil penelitian menunjukkan Ketidakjelasannya lokasi pelayanan IMB pada kantor BPPT Kabupaten Mamuju, masyarakat masih sering dijumpai mengurus IMB di Kantor Dinas Tata Ruang dan Kebersihan yang sebenarnya sudah dilimpahkannya ke BPPT dalam pelayana IMB.

Analisis kejelasan Informasi dan pengaduan pelayanan adalah masukan dari masyarakat baik berupa informasi, saran, pendapat, tanggapan atau pengaduan, dalam upaya perbaikan pelayanan kepada pemberi pelayanan. Kejelasan informasi pengaduan dalam pelayanan IMB pada Kantor BPPT Kabupaten Mamuju telah memberikan ruang kepada masyarakat untuk menyampaikan keluhan pelayanan yang dialaminya, pengaduan melalui kotak saran dan call center yang telah disediakan dengan jelas kepada masyarakat. Sebagaimana yang dinyatakan oleh Sutopo \& Suryanto (2003), bahwa organisasi 
pemberi pelayanan wajib menangapi dan menghadapi keluhan masyarakat tersebut untuk kepentingan dan kepuasan pelanggan. Transparansi di perlukan suatu proses konsultasi yaitu adanya dialog antara pemerintah dan masyarakat sebagai penerima layanan agar dapat masyarakat memberikan saran dan keluhan terhadap pelayanan yang diberikan oleh penyelenggara pelayanan (Smith, 2004).

\section{PENUTUP}

Kesimpulan

$$
\text { Dari penelitian tentang }
$$

transparansi pelayanan izin mendirikan bangunan (IMB) pada Kantor BPPT Kabupaten Mamuju dapat disimpulkan bahwa dalam penerapan transparansi pelayanan IMB belum terimplementasikannya sesuai dengan apa yang diharapkan oleh masyarakat, yakni dari segi manajemen penyelenggaraan pelayanan yang belum terpublikasikan kepada masyarakat/pelanggan secara jelas. Demikian juga dalam persyaratan teknis dan administrasi pelayanan, pejabat yang berwenang dan bertanggung jawab, waktu penyelesaian pelayanan, lokasi pelayanan, standar pelayanan dan janji pelayanan yang belum terinformasikan secara jelas dan tepat kepada masyarakat. Sedangkan yang memenuhi proses penerapan transparansi pelayanan IMB yakni dari segi prosedur pelayanan, perincian biaya dan proses pengaduan pelayanan.

Saran

Adapun saran dalam penerapan transparansi pelayanan izin mendirikan bangunan pada badan Pelayanan Periziinan Terpadu Kabupaten Mamuju adalah perlunya ditingkatkan terutama dalam manajemen penyelenggaraan pelayanan, persyaratan teknis dan administrasi pelayanan, waktu penyelesaian pelayanan, pejabat yang bewenag dan bertanggung jawab, janji pelayanan, lokasi pelayanan dan standar pelayanan agar dapat diinformasikan secara jelas dan tepat kepada masyarakat/pelanggan. Sebab dengan adanya transparansi pelayanan yang diterapkan dalam pelayanan perizinan akan membangun citra aparat pemerintah terhadap masyarakat dalam pelayanan publik untuk selalu melayani, melakukan dan memberi dengan pelayanan yang berkualitas.

\section{DAFTAR PUSTAKA}

Brannen Julia. (2005). Memadu Metode Penelitian Kualitatif dan Kuantitatif, Yogyakarta : Pustaka Pelajar

Dunan Bernadus. (2011). Transparansi Pelayanan Pada Perusahaan Daerah Air Minum (PDAM) Kota Ambon. Thesis MAP UNHAS.

Dwiyanto Agus. (2008). Mewujudkan Good Governance Melalui Pelayanan Publik. Yogyakarta: gajah Mada Univertity Press.

Frederickson George H. \& Smith B.Kevin. (2002). The Public Administration Theory Primer. USA : Westview Press

Keban Y.T. (2008). Enam Dimensi Strategis Administrasi Publik. Yogyakarta. Gava media.

Ratminto \& Winarsih Atik Septi. (2005). Manajemen Pelayanan, Penerbit Pustaka Pelayaran. PT. Yogyakarta

Ratminto \& Winarsih Atik Septi. (2014). Manajemen Pelayanan Pengembangan Model Konseptual, Penerapan Citizen's Charter, dan Standar Pelayanan Minimal. Yogyakarta: Pustaka Pelajar

Sutopo \& Suryanto Adi. (2003). Pelayanan Prima, Penerbit Lembaga Administrasi Negara Republik Indonesia, Jakarta.

Sugiono. (2011). Metode Penelitian Kombinasi, Mixed Methods. Bandung, CV. Alfabeta. 
Available Online at http://journal.umgo.ac.id/index.php/Publik

Publik : (Jurnal Ilmu Administrasi) Vol 7 (1), Juni 2018

Smith Rex Deighton. (2004). Regulatory

Transparency in OECD Countries:

Overview, Trends a,d

Challengers. Australian: Jurnal of

Publik Administration. 63: 66-73 